\title{
THE EFFECT OF SALINITY ON LIBYAN SOFT WHEAT TRITICUM AESTIVUM L AT GERMINATION STAGE
}

\author{
Amal Faraj Ehtaiwesh ${ }^{1}$ and Fatma Hossen Rashed ${ }^{2}$ \\ ${ }^{1,2}$ Department of plant science, University of Zawia, Libya \\ ${ }^{1}$ E- mail address: Eamal@ksu.edu, Tel: +21892 786-9017
}

\begin{abstract}
Salinity is the major abiotic stress that reduces plant growth and productivity worldwide. The objectives of this study were to quantify the effects of salinity on seedling characters of soft wheat Triticum aestivum $L$ genotypes and to define if responses varied among wheat genotypes. For that, 12 genotypes of wheat were evaluated for the salinity tolerance in artificially induced with $\mathrm{NaCl}$ at their germination and early seedling stage. Seeds were subjected to four levels of salinity $(0,50,100$ and $150 \mathrm{mM} \mathrm{NaCl})$ and raised for eight days under optimum conditions to calculate the final germination percentage, speed of germination, mean daily germination, shoot and root length, and seedling fresh and dry weight. The response of genotypes were divers among the studied traits. At higher concentration of $\mathrm{NaCl}(100$ and $150 \mathrm{mM})$, speed of germination and mean daily germination were delayed and final germination percentage was decreased. At higher salinity level, significant decrease in shoots and roots length, seedling dry weight and seedling vigor. Additionally, the study showed considerable variation in salinity tolerance among wheat genotypes for studied traits. The study concluded that there is a genetic variability among genotypes and that genotypes varied in their response to salinity stress and that genotypes Sabha, Salambo, Makkawi and Bushi were the most tolerant genotypes.
\end{abstract}

Keywords: Triticum aestivum L, germination, salinity tolerance, seedling vigor.

\section{Introduction}

Agricultural productivity is cruelly affected by soil salinity. Soil and water salinity are caused by the presence of excessive amounts of salts. At least 20 percent of the world's irrigated land is salt affected and/or irrigated with saline waters (Qadir et al., 2008, Shrivastava and Kumar, 2015). In addition, additional of about two million of cropping land are affected by salinity every year (Rengasamy, 2006; Tuteja, 2007, Jamil et al., 2011, Munns and Gilliham, 2015). Because of salinization increases of agriculture land, it is projected that about $50 \%$ loss of cropping acreage by the middle of the 21st century (Wang et al, 2007, Patel et al., 2011, Shahbaz and Ashraf, 2013). In arid and semi-arid regions, high temperatures during the summer season causes severe evaporation losses, hence leaving behind large amounts of salts. In Libya, specifically in the North close to the coast of the Mediterranean Sea, the problem of salinity in agriculture becomes more and more severe because of too much irrigation water is 
applied for crop production. In addition, bad drainage systems and hot weather increase evaporation which tends to create salinity. Soil salinity causes great losses to agriculture by lowering the yields of various crops.

Wheat is moderately tolerant to salinity stress (Shannon, 1997). However, salt stress effects plant as it reduces water potential, cause ions imbalance, disturbances in ion homeostasis, and toxicity (Maas, and Grattan. 1999; Munns, 2002; Sairam, 2002). This results in changing the water status, which leads to initial growth reduction and limitation of plant productivity due to reduced cell growth and leaf area (Acevedo et al., 2002). Under saline condition, relative water content, leaf water potential, water uptake, and water use efficiency decreased (Nishida et al., 2009). Plant salinity tolerance is the inherent ability of the plant species to tolerate the effects of high salts without a significant adverse effect on the plant (Munns et al., 2006). Some plants have developed different adaptation mechanisms, which include the accumulation of osmo-protectants, exclusion of sodium and chloride, tissue tolerance to accumulated sodium and chloride (Rathinasabapathy, 2000; Zhang et al., 2001; Munns and Tester, 2008; Ashraf et al., 2010).

Crops have different sensitivity to salinity at different growth stages. Many studies showed that plants are tolerant during germination stage and become more sensitive to salinity during the seedling stage (Kingsbury et al., 1986; Maas et al., 1999, Giuffrida e al., 2016). Seed germination is a factor which contributes to yield of the plants. Among the abiotic factors, salinity is considered an important problem for wheat germination, because it influences the rate of water up take by seeds which is essential for plant growth and development. Many studies point out that crops are more sensitive to salinity during the seedling stage than during germination, and this depends on the crop ((Maas et al., 1999). A study by Maas and his team on corn and wheat reported that the dry matter yields of these plants are reduced as the concentrations of salt increased (Maas et al. 1983). Studies showed that there is a linear decrease in yield components as the level of salinity increased. However, these findings recommended that seedling emergence and early seedling growth stages are most sensitive to salinity (Zeng and Shannon, 2000). Salinity levels in soil and/or irrigation water have variable effects on different plant species. Plant species and genotypes within species show differential responses to salinity stress (Djanaguiraman and Prasad, 2013; Namvar et al., 2018). To our knowledge, screening Libyan soft wheat germplasms to salinity stress and understanding the genetic variability for seedling character was not studied in detail. Therefore, the objective of this study is to evaluate Libyan soft wheat genotypes for salinity tolerance at the germination stages and to determine seedling growth traits associated with salinity tolerance.

\section{Materials and Methods}

This study was conducted in controlled environment facilities at the Plant Science Department, University of Az Zawia, Libya. Experiments were conducted in fall of 2018 to 
determine the impact of salinity stress on germination and seedling characteristic of soft wheat genotypes.

\section{Plant Material}

12 genotypes of Libyan soft wheat were used in this study and these genotypes were obtained from Libyan National GenBank in Tajoura. These genotypes include some very old local genotypes that include: (Fritcea, Makkawi, Bushi, Solala 22); old improved genotypes include: (Sidi El-Masry, El-Mukhtar, Bohot 208, Germa, Sabha); New improved genotypes include: (Abu Al-Joud, Abu Al-Khair); and imported genotype include (Salambo).

\section{Experimental Details and Growth Conditions}

The experiments were conducted during 2018 at Plant Science Department, University of Zawia, Libya. Four different concentrations of saline solution prepared with tap water (0, 50, 100 and $150 \mathrm{mM} \mathrm{NaCl}$ with electric conductivity [EC] value of $<0.7,4.5,8.3$ and $15.5 \mathrm{dSm}^{-1}$ ) were used for salinity treatments and tap water used as control solution $(0 \mathrm{mM} \mathrm{NaCl})$. Healthy seeds of each genotype were surface sterilized with sodium hypochlorite solution $(5 \%)$ for three minutes, washed with distilled water, air dried and used for the experiment. A set of 20 seeds were placed in a petri dish with Whatman no. 1 filter paper disc; was moisturized $5 \mathrm{~mL}$ of the different saline solutions $(0,50,100$ and $150 \mathrm{mM} \mathrm{NaCl})$. The filter paper was moisturized on daily basis till the end of experiment and filter papers were changed once in every two days to prevent salt accumulation due to evaporation. The seeds moisturized with tape water instead of $\mathrm{NaCl}$ solution saved as absolute control treatment for the experiment. A total of four replications used for control and $\mathrm{NaCl}$ treatments. All the petri dishes were placed in the dark throughout the germination period (total 8 days) at room temperature $24 \pm 2^{\circ} \mathrm{C}$. Seeds were considered germinated (Feekes 0.9 ) when both shoot, and root extended more than $2 \mathrm{~mm}$ from the seed (Islam et al., 2012). The following traits were recorded during germination period and 8 days after sowing.

\section{Germination Traits}

Germination per cent $(G \%)$ was expressed according to Nasri et al., 2011. The following formula was used to calculate $G \%$ :

$$
G \%=(N S G \div T N S S) \times 100
$$

Where NSG is the number of seeds germinated at the end of the experiment ( 8 day after sowing). TNSS is the total number of seeds sown.

Germination index (GI \%) in each $\mathrm{NaCl}$ treatment was calculated according to the equation given by Karim et al. (1992). The following formula was used to calculate GI \%:

$$
\boldsymbol{G I} \%=(\% \boldsymbol{G N a C l} \div \% \boldsymbol{G C}) \times \mathbf{1 0 0}
$$


Where \% $\mathrm{GNaCl}$ is per cent germination at different $\mathrm{NaCl}$ treatments. \% GC is per cent germination in control treatment.

The germination rate (GR) was calculated according to the equation given by Rubio-Casal, (2003). The count of germinated seeds was recorded at 24 hours interval from sowing till the end of experiment ( 8 day after sowing) and used to calculate GR. The following formula was used to calculate GR:

$$
G R=(n 1 t 1)+(n 2 t 2)+\cdots+(n x t x) \div T N G S
$$

Where $n_{1}$ is the number of seeds germinated on the first day of germination, $t_{1}$ is the number of days taken for first germination and TNGS is the total number of seeds germinated.

Mean daily germination (MDG) was calculated as per Gairola et al. (2011). The following formula was used to calculate MDG:

$$
M D G=T N G S \div T N D G
$$

Where $T N G S$ is total number of germinated seeds and $T N D G$ is total number of days taken for final germination.

\section{Early Seedling Traits}

Morphological traits viz., shoot and root length and dry weight were subsequently measured from 5 uniform seedlings from each replication at early seedling stage (Feekes 1). Selected seedlings were dissected and shoot, and root length were recorded. The length from the seed to the tip of the root and leaf blade was calculated to measure the root length and shoot length, respectively. The fresh weight of shoot and root was recorded using a weighing balance, and then dried in an oven maintained at $40{ }^{\circ} \mathrm{C}$ till it attains stable weight. After that, shoot and root dry weights were recorded. Using the morphological traits, the salinity tolerance index (STI) and Seedling vigor index (SVI) were calculated.

The following formula was used to calculate STI (Tsegay et al., 2014):

$$
S T I=(S d w N a C l \div S d w C) \times 100
$$

Where $S d w N a C l$ is dry weight of seedling from $\mathrm{NaCl}$ treatment. $S d w C$ is dry weight of seedling from control treatment.

The following formula was used to calculate SVI (Abdoli1 et al. 2013):

$$
S V I=(S L \times G \%) 100
$$

Where $S L$ is seedling length and $G \%$ is germination per cent. 


\section{Statistical Analysis}

The experimental design was a randomized complete block design (RCBD) with four replications. Analysis of variance (ANOVA) performed on genotypes using generalized linear model (GLM) procedure in SAS 9.4 (SAS Institute Inc., Cary, NC, USA) for seed germination and related traits. Separation of means was carried out using the least significant differences (LSD; $P<0.05$ ). The means were compared using Ducan's multiple range test.

\section{Results}

Significant differences were found among the genotypes for all the traits measured. Analysis of variance results showed that salinity had significant effect $(\mathrm{P}<0.05)$ on germination \%, germination index, mean daily germination, speed of germination and seedling vigor index. Whereas salinity and genotype interactions were significant $(\mathrm{P}<0.05)$ for almost all germination traits except for on germination \%, germination index Table (1). Regarding seedling traits, the result showed that salinity treatments, genotype and their interaction had significant effect $(\mathrm{P}<0.05)$ on all studied seedling traits excluding seedling fresh weight Tables (1) and (2).

\section{Germination Parameters}

Most of germination traits of wheat genotypes was significantly affected by the salinity stress $(\mathrm{p}<0.05)$ Tables (1) and (2). Germination per cent was reduced from $100 \mathrm{mM} \mathrm{NaCl}$ salt concentration onwards for almost all the genotypes. Generally increasing level of salinity stress caused decrease in germination per cent over control. Still, in some genotypes, the germination per cent was not affected at $50 \mathrm{mM} \mathrm{NaCl}$ but decreased by $18 \%$ at $150 \mathrm{mM} \mathrm{NaCl}$ over the control (0 mM NaCl; Fig. 1a). Salinity stress significantly decreased mean daily germination (MDG) in all genotypes. However, in some genotypes, moderate salinity decreased mean daily germination by lesser extent and severe stress decreased to a greater extent.

Table (1): Probability Values of Effects of Salinity (S), Genotype (G) And Salinity X Genotype Interaction on Germination and Early Seedling Traits at Germination Stage (Feekes 0.9)

\begin{tabular}{|c|c|c|c|}
\hline & \multicolumn{3}{|c|}{ Variables } \\
\hline Traits & Salinity (S) & Genotype (G) & SxG \\
\hline Germination per cent (\%) & $<.0001$ & 0.0416 & 0.8613 \\
\hline Germination index (GI; \%) & $<.0001$ & 0.0291 & 0.7540 \\
\hline Mean daily germination (MDG) & $<.0001$ & 0.0003 & 0.0447 \\
\hline Speed of germination (SG) & $<.0001$ & $<.0001$ & $<.0001$ \\
\hline Shoot length (cm) & $<.0001$ & $<.0001$ & 0.0392 \\
\hline
\end{tabular}




\begin{tabular}{|c|c|c|c|}
\hline Root length $(\mathrm{cm})$ & $<.0001$ & 00148 & 0.0256 \\
\hline Seedling length $(\mathrm{cm})$ & $<.0001$ & $<.0001$ & 0.0051 \\
\hline Seedling fresh weight $(\mathrm{g})$ & $<.0001$ & 0.0018 & 0.0905 \\
\hline Seedling dry weight $(\mathrm{g})$ & $<.0001$ & 0.0001 & 0.0164 \\
\hline Salt tolerance index (STI) & $<.0001$ & $<.0001$ & 0.0036 \\
\hline Seedling vigor index (SVI) & $<.0001$ & $<.0001$ & 0.0578 \\
\hline
\end{tabular}

Table (2) Effect of Salinity Stress on Studied Traits Under Different Salinity Levels in Soft Wheat at Germination Stage (Feekes 0.9).

\begin{tabular}{|c|c|c|c|c|}
\hline \multirow{2}{*}{ Traits } & \multicolumn{3}{|c|}{ NaCl levels (mM) } & \\
\cline { 2 - 5 } & $\mathbf{0}$ & $\mathbf{5 0}$ & $\mathbf{1 0 0}$ & $\mathbf{1 5 0}$ \\
\hline Germination percent (\%) & $99^{\mathrm{a}}$ & $97^{\mathrm{a}}$ & $91^{\mathrm{b}}$ & $83^{\mathrm{c}}$ \\
\hline Germination index (\%) & $100^{\mathrm{a}}$ & $98^{\mathrm{b}}$ & $85^{\mathrm{c}}$ & $85^{\mathrm{c}}$ \\
\hline Mean daily germination & $6.3^{\mathrm{a}}$ & $5.7^{\mathrm{b}}$ & $4.3^{\mathrm{c}}$ & $2.8^{\mathrm{d}}$ \\
\hline Germination Speed & $14^{\mathrm{a}}$ & $13^{\mathrm{b}}$ & $8^{\mathrm{c}}$ & $6^{\mathrm{d}}$ \\
\hline Shoot length (cm) & $8^{\mathrm{a}}$ & $7^{\mathrm{b}}$ & $6^{\mathrm{c}}$ & $4^{\mathrm{d}}$ \\
\hline Root length (cm) & $9^{\mathrm{a}}$ & $8^{\mathrm{b}}$ & $5^{\mathrm{c}}$ & $3^{\mathrm{d}}$ \\
\hline Seedling length (cm) & $17^{\mathrm{a}}$ & $15^{\mathrm{b}}$ & $10^{\mathrm{c}}$ & $7^{\mathrm{d}}$ \\
\hline Seedling fresh weight $(\mathrm{g})$ & $1.5^{\mathrm{a}}$ & $1.4^{\mathrm{b}}$ & $1.3^{\mathrm{c}}$ & $1.2^{\mathrm{d}}$ \\
\hline Seedling dry weight $(\mathrm{g})$ & $0.59^{\mathrm{a}}$ & $0.48^{\mathrm{b}}$ & $0.32^{\mathrm{c}}$ & $0.16^{\mathrm{d}}$ \\
\hline Salt tolerance index & $100^{\mathrm{a}}$ & $88^{\mathrm{b}}$ & $62^{\mathrm{c}}$ & $32^{\mathrm{d}}$ \\
\hline Seedling vigor index & $16^{\mathrm{a}}$ & $15^{\mathrm{b}}$ & $10^{\mathrm{c}}$ & $6^{\mathrm{d}}$ \\
\hline
\end{tabular}

* Individual value is the mean of 12 genotypes under different salinity levels. Values followed by different letters are significantly different according to Duncan's multiple range test $(P<0.05)$.

The results of salinity stress were almost prominent from $150 \mathrm{mM}$ salt concentration for most wheat genotypes resulting into reduction in mean daily germination (MDG). In some genotypes the per cent reduction over the control reached 65\% in Sidi Elmassry genotype Figure (1b).

Speed of germination of wheat genotypes were significantly affected because of salinity stress from $50 \mathrm{mM} \mathrm{NaCl}$ concentration onwards.

There was substantial reduction in the speed of germination for almost all the genotypes. however, the reduction was higher for few wheat genotypes in case of $100 \mathrm{mM}$ and $150 \mathrm{mM}$ 
$\mathrm{NaCl}$ concentration. At $150 \mathrm{mM} \mathrm{NaCl}$ concentration, the percent reduction over the control in Abu Al-Joud genotype was 65\%, where as in more tolerant genotypes the per cent reduction over the control was $46 \%$ Figure (1c). Also, the results displayed small reduction in germination index (GI) at moderate and high concentrations with the highest decrease at 150 $\mathrm{mM} \mathrm{NaCl}$. Figure (2a). Results regarding salt tolerance (ST) of different soft wheat genotypes showed that genotypes MAKKAWI, SALAMBO and Sabha were tolerant to salinity stress at germination stage, whereas genotypes ABU AL-KHAIR, GERMA and SOLALA 22 were sensitive to salinity stress Figure (2b). High level of salinity (100 to $150 \mathrm{mM} \mathrm{NaCl}$ increasingly decreased seedling vigor index. Low salinity level $(50 \mathrm{mM} \mathrm{NaCl})$ showed small reduction on seedling vigor index. Figure (2c) shows that the highest seedling vigor index was observed in control, while salinity at $150 \mathrm{mM} \mathrm{NaCl}$ decreased significantly seedling vigor index by $(70 \%)$. Speed of germination of wheat genotypes were significantly affected because of salinity stress from $50 \mathrm{mM} \mathrm{NaCl}$ concentration onwards.

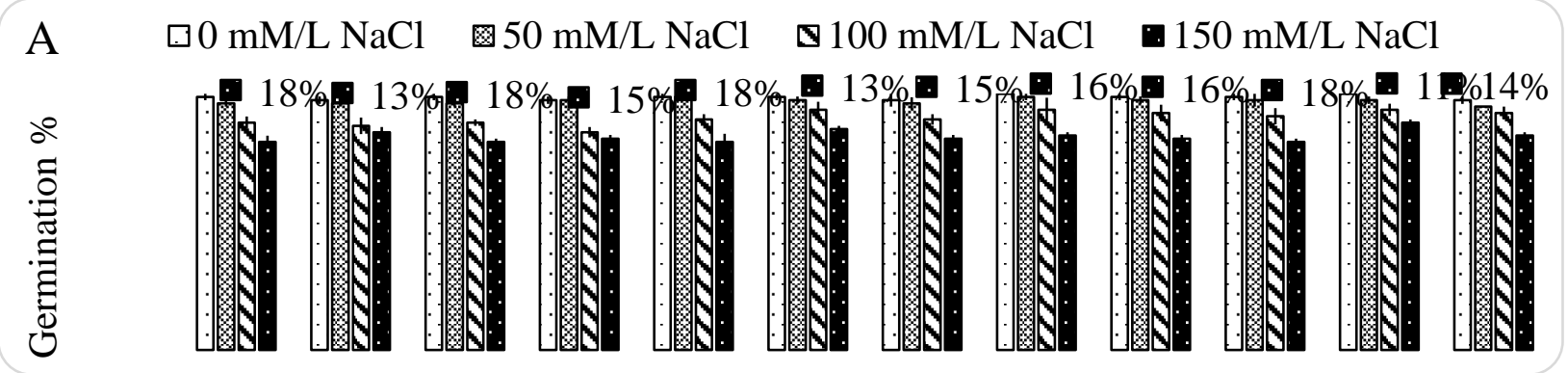

$\mathrm{B}$
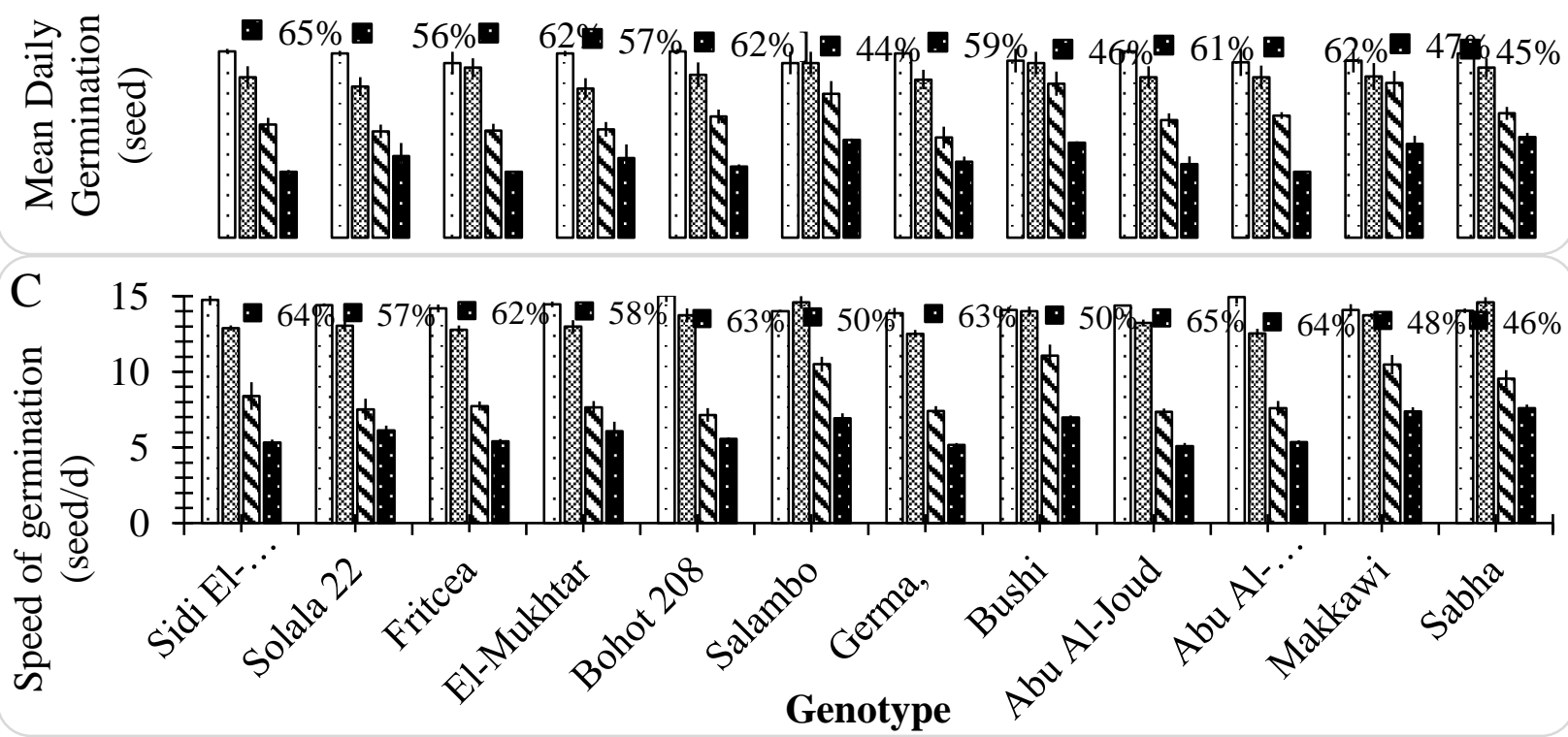

Figure (1): The Effects of Different Salinity Levels (0, 50, 100, $150 \mathrm{Mm} \mathrm{Nacl)} \mathrm{on} \mathrm{(A)} \mathrm{Germination}$ Percentage, (B) Mean Daily Germination and (C) Germination Speed of Twelve Soft Wheat Genotypes. Percent Decline of each Trait Due to High Level of Salinity (150 Mm Nacl) as Compared to Control is Indicated. Vertical Lines on Top of Bars Indicate Standard Error of Means (n = 4). 

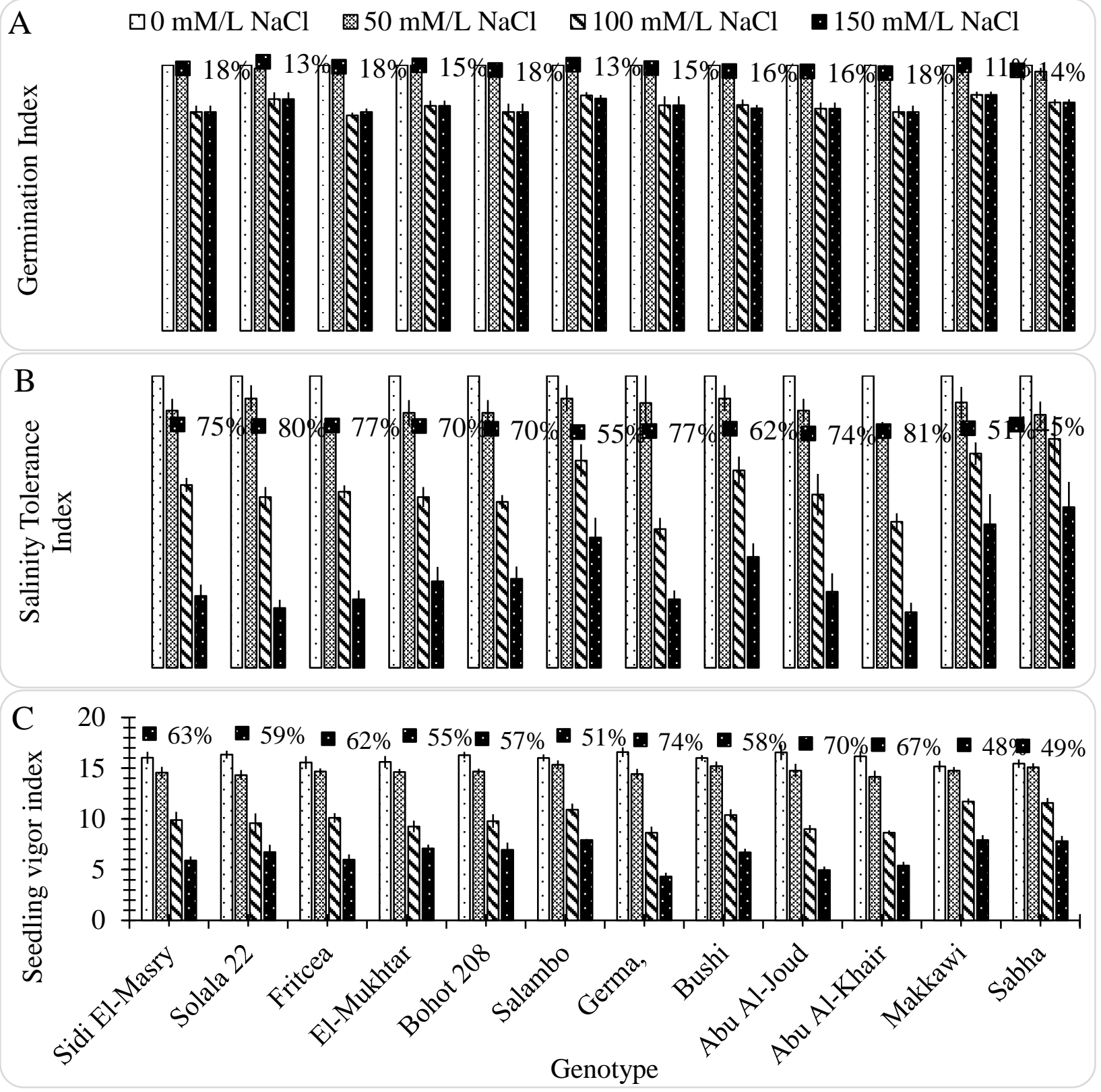

Figure (2): The Effects of Different Salinity Levels (0, 50, 100, $150 \mathrm{Mm}$ Nacl) On (A) Germination Index, (B) Salinity Tolerance Index and (C) Seedling Vigor Index of Twelve Soft Wheat Genotypes. Percent Decline of Each Trait Due to High Level of Salinity (150 Mm Nacl) as Compared to Control is Indicated. Vertical Lines on Top of Bars Indicate Standard Error of Means (n = 4).

\section{Seedling Parameters}

Most of seedling parameters decreased with increasing salinity level Tables (1) and (2). Under non-saline conditions genotypes showed no substantial differences in terms of shoot length. However, under both levels $100 \mathrm{mM}$ and $150 \mathrm{M}$ of $\mathrm{NaCl}$ condition there were significant 
differences in response of genotypes to salinity levels Table (2). In addition, salinity caused a significant $(\mathrm{p}<0.05)$ reduction on root length and seedling length at the higher $\mathrm{NaCl}$ concentration $(100,150 \mathrm{mM} \mathrm{NaCl})$.Increase in the salinity from 0 to $50 \mathrm{mM} \mathrm{NaCl}$ had small effect on root and seedling length, though more increase from $100 \mathrm{mM} \mathrm{NaCl}$ onwards significantly reduced the root length and seedlings length Figure (3a) and (3b).

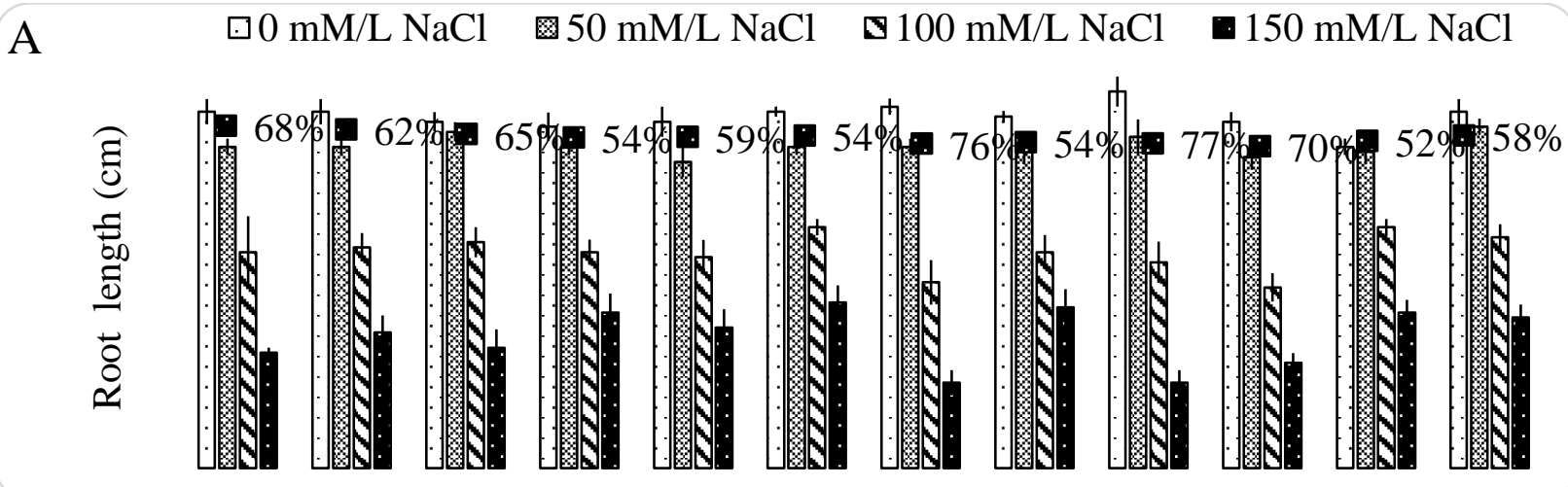

B
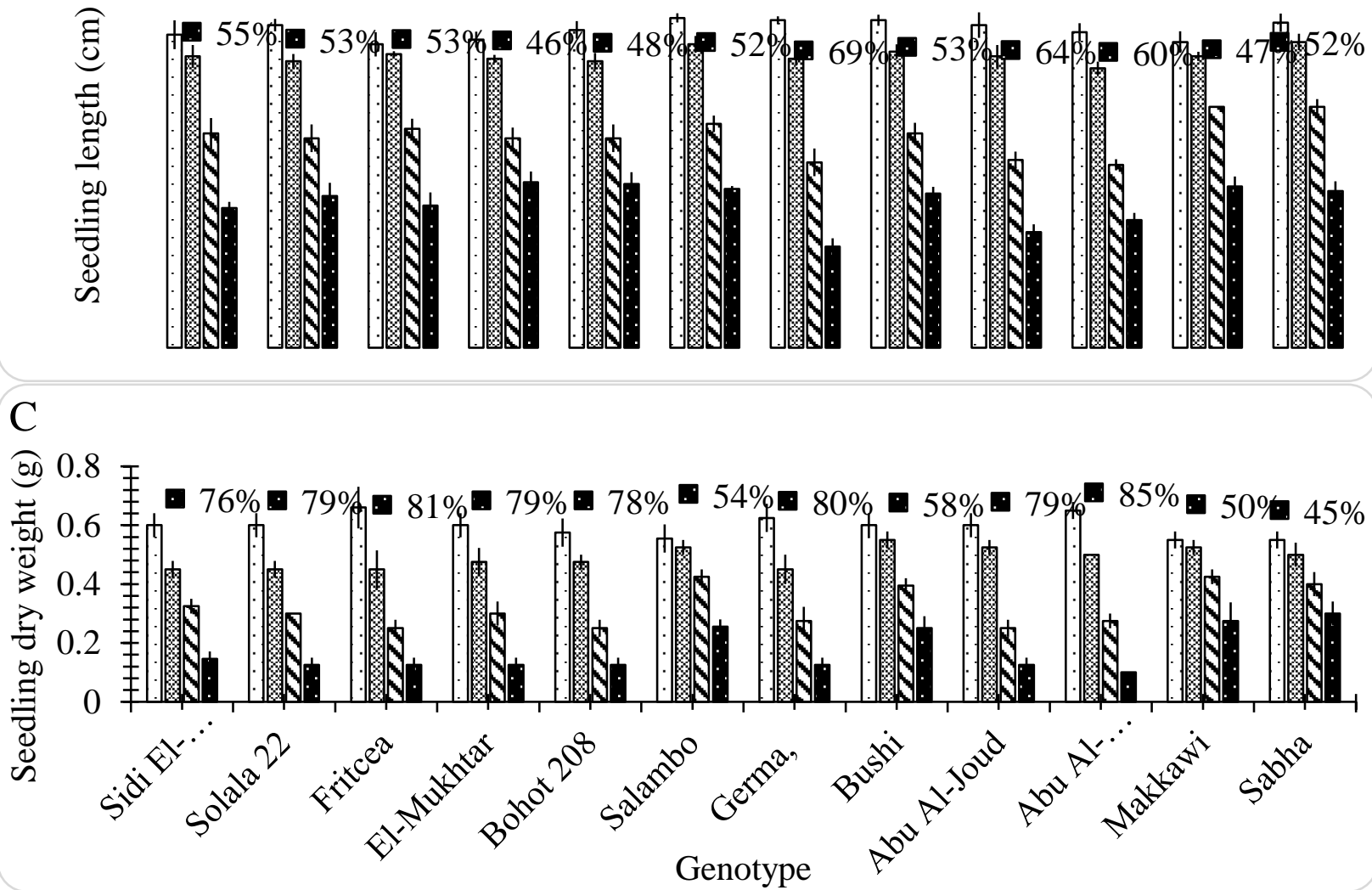

Figure (3): The Effects of Different Salinity Levels (0, 50, 100, $150 \mathrm{Mm}$ Nacl) on (A) Root Length (Cm), (B) Seedling Length and (C) Seedling Dry Weight of Twelve Soft Wheat Genotypes. Percent Decline of Each Trait Due to High Level of Salinity (150 Mm Nacl) As Compared to Control Is Indicated. Vertical Lines on Top of Bars Indicate Standard Error of Means $(n=4)$. 
However, root length was more affected by salinity stress than shoot length. The result indicated that some genotypes were more tolerance to salinity in root growth as compared with other genotypes. For example, genotypes GERMA, ABU AL-JOUD and ABU AL-KHAIR showed a percent reduction of above $70 \%$, whereas genotypes MAKKAW, SALAMBO and SABHA showed a percent reduction of 52\%,54\%, 58\% respectively Figure (3a). The seedling dry weight displayed a significant reduction in response to the increasing levels of salinity $(\mathrm{p}<0.05)$. under effect of $150 \mathrm{mM} \mathrm{NaCl}$, the seedling dry weight in some genotypes decreased by $85 \%$ compared to those of the control Figure (3c) and Table (2).

The genotypes were ranked based on the seedling vigor index, such that those with the smallest and largest percent reduction over the control were ranked respectively as the most and least tolerant genotypes at $150 \mathrm{mM} \mathrm{NaCl}$. Based on that, genotypes were separated into two categories. (1) tolerant to salinity at germination stage (MAKKAWI, SABHA, BUSHI AND SALAMBO), (2) susceptible to salinity at germination stage (SIDI EL-MASRY, SOLALA 22, FRITCEA, EL-MUKHTAR, BOHOT- 208, ABU AL-JOUD and ABU ALKHAIR).

\section{Discussion}

The environmental condition in the North of Libya is characterized by soil and water salinity resulting from shortage of rain which influences negative growth and productivity of crop plants. To avoid stress environments, plants have evolved complex mechanisms to counter $\mathrm{NaCl}$ toxicity and low water potential in growth condition caused by salinity (Munns and Tester, 2008). Salinity affects early seedling growth of plants by changing water relations due to salt gathering in intercellular spaces (Zhang et al., 2006). From the results of this study it can be concluded that seeds of different wheat genotypes were susceptible to high concentrations of salt solutions at germination stage which was agreed with the works of (Ungar et al., 1996; Gul et al., 1999). This study indicated that during the germination phase the seeds were sensitive to salinity stress. This finding agreed with many studies on the effect of salinity stress on seed germination under saline condition (Ashraf et al., 2010; Farooq et al., 2011). The reduction of seed germination may be due to (1) damage of viability at higher salinity level (2) delaying germination of seeds at salinities that cause some stress to but not percent germination (3) due to salinity induced high oxidative stress as stated in other studies (Gulzar et al., 2001; Amor et al., 2005). This study found that the effect of salinity stress was finally inhibitory at $150 \mathrm{mM} \mathrm{NaCl}$ concentrations for almost all wheat genotypes except SALAMBO, MAKKAWI, SABHA and BSHI. In this study the higher concentration of salinity has a more distinct effect on root length as compared with shoot length maybe since roots are directly exposed to salinity solution. Similar tendency was detected by other studies ((Jamil and Rha, 2004). The reduction in root and seedling growth may be due to the toxic effects of the increased level of $\mathrm{NaCl}$ concentration in addition to decrease in water uptake by the plant roots. 


\section{Conclusions}

In conclusion, the results of this study conclude that some wheat genotypes such as SALAMBO SABHA and MAKKAWI appeared to be moderately salinity tolerant at germination stage than other genotypes of wheat involved in this study. Whether such results can be achieved under natural condition and at later growth stages needs the significance of field assessment through screen field trials. Besides, comparative physiological and biochemical foundation of such tolerance amongst genotypes similarly needed.

\section{Acknowledgements}

The authors thank Mr. Ali shridi and his team at Libyan National GenBank in Tajoura for providing seeds of wheat genotypes. authors are grateful to University Az Zawia for providing equipment's for the study.

\section{References}

- $\quad$ Abdoli1, M., M. Saeidi, M. Azhand, S. Jalali-Honarmand, E. Esfandiari, and F. Shekari. 2013. The Effects of different levels of salinity and indole-3-acetic acid (IAA) on early growth and germination of wheat seedling. Journal of Stress Physiology and Biochemistry 4: 329-338.

- Acevedo, E., P. Silva, and H. Silva. 2002. Wheat growth and physiology. In: Curtis, B. C., S. Rajaram and H. G. Macpherson (Eds.) Bread Wheat Improvement and Production, FAO Plant Production and Protection Series, No. 30. Food and Agriculture Organization of the United Nations, Rome, Italy.

- Amor, N. B., Hamed K. B., Debez, A., Grignon, C., Crabbedly. 2005. Physiological and antioxidant responses of perennial halophyte Crithmum maritimum to salinity. Plant Science 4: 889-899.

- Ashraf, M. A., Ashraf, M., and Ali, Q. 2010. Response of two genetically diverse wheat cultivars to salt stress as different growth stages: leaf lipid peroxidation and phenolic contents. Pakistan Journal of Botany. 42: 559-565.

- Ashraf, M., N. A. Akram, R. N. Arteca, and M. R. Foolad. 2010. The physiological, biochemical, and molecular roles of brassinosteriods and salicylic acid in plant processes and salt tolerance. Critical Reviews in Plant Science 29: 162-190.

- Djanaguiraman, M. and Prasad, P. V.V. 2013. Effects of salinity on-ion transport, water relations and oxidative damage. Pages 89-114 In: Ecophysiology and responses of plants under salt stress. Edit Ahmad, P., Azooz, M.M., Prasad, M.N.V. Springer New York. 
- Farooq, M., M. Habib, A. Rehman, A. Wahid and R. Munir. 2011. Employing aqueous allelopathic extracts of sunflower in improving salinity tolerance of rice. Journal of Agriculture and Social Sciences 7: 75-80.

- Gairola, K.C., A. R. Nautiyal, and A. K. Dwivedi. 2011. Effect of temperatures and germination media on seed germination of Jatropha Curcas Linn. Advances in Bioresearch 2: 66-71.

- Giuffrida, F., Carla, C., Angelo, M., Cherubino, L. 2016. Effects of salt stress imposed during two growth phases on cauliflower production and quality. Journal of Science and Food Agriculture. 97: 1552-1560.

- Gul, B.; Weber, D. J. 1999. Effect of salinity, light, and temperature on germination in Allenrolfea occidentalis . Can. J. Bot77:240-246.

- Gulzar, S., Khan, M. A. 2001. Seed germination of a halophytic grass Aeluropus logopoides Annals of Botany $87: 319-324$.

- Islam, R., A. Mukherjee, and M. Hossain. 2012. Effect of osmopriming on rice seed germination and seedling growth. J. Bangladesh Agric. Univ. 10(1): 15-20.

- Jamil, M. and E.S. Rha. 2004. The effect of salinity on germination and seedling of sugarbeet (Beta vulgaris L.) and cabbage (Brassica oleracea L.) Korean Journal of Plant Protection 7: 226-232.

- Jamil A., Riaz S., Ashraf M., Foolad M.R. 2011. Gene expression profiling of plants under salt stress. Crit. Rev. Plant Sci. 30(5):435-458.

- Karim, M.A., N. Utsunomiya, and S. Shigenaga. 1992. Effect of Sodium on germination and growth of hexaploid triticale at early seedling stage. Japanese Journal of Crop Science 61: 279284.

- Kingsbury, R. w., and Eepstein,E. 1986. Salt Sensitivity in Wheat1 Plant Physiol. 80: 651654.

- Maas, E.V., G.J. Hoffman, G.D. Chaba, J.A. Poss and M.C. Shannon. 1983. Salt sensitivity of corn at various growth stages. Irrig. Sci. 4:45-57.

- Maas,E. V. and Grattan, S. R. 1999. Crop Yields as Affected by Salinity. In W. Skaggs and J. Van Schlifgaarde, eds, Agriculture Drainage. Agron. Monograph 38. ASA, CSSA, SSSA, Madison, WI.

- Munns, R. 2002. Comparative physiology of salt and water stress. Plant Cell and Environment 25: $239-250$. 
- Munns, R., R. A. James, and A. Lauchli. 2006. Approaches to increasing the salt tolerance of wheat and other cereals. Journal of Experimental Botany 57: 1025-1043.

- Munns, R., and M. Tester. 2008. Mechanisms of salinity tolerance. Annual Review of Plant Biology 59: 651-681.

- Munns, R. and Gilliham, M. 2015. Salinity tolerance of crops-what is the cost? New physiologist 208: 668-673.

- Namvar, A., Seyed Sharifi R., Hadi H. 2018. A Study into the Effects of Salt Stress on Germination Components of Different Wheat (Triticum aestivum) Cultivars. Iranian J. Seed Res. 4 (2) :1-12.

- Nasri, N., R. Kaddour, M. Rabhi, C. Plassard, and M. Lachaâl. 2011. Effect of salinity on germination, phytase activity and phytate content in lettuce seedling. Acta Physiologiae Plantarum, 33: 935-942.

- Nishida, K. N. M. Khan, and S. Shiozawa. 2009. Effects of salt accumulation on the leaf water potential and transpiration rate of pot-grown wheat with a controlled saline groundwater table. Soil Science and Plant Nutrition 55: 375-384.

- Patel B.B., Patel Bharat.B., Dave R.S. 2011. Studies on infiltration of saline-alkali soils of several parts of Mehsana and Patan districts of north Gujarat. Journal of Applied Technology Environ. Sanitation.1(1):87-92.

- Qadir, M., Tubeileh, A., Akhtar, J., Larbi, A., Minhas, P. S., and Khan, M. A. 2008. Productivity enhancement of salt -affected environments through crop diversification. Land Degradation Develop. 19: 429-453.

- Rathinasabapathy, B. 2000. Metabolic engineering for stress tolerance: installing osmoprotectant synthesis pathways. Annals of Botany 86: 709-716.

- Rengasamy, P. 2006. World salinization with emphasis on Australia. Journal of Experimental Botany. 5: 1017-1023.

- Rubio-Casal, A.E., J. M. Castillo, C. J. Luque, and M. E. Figueroa. 2003. Influence of salinity on germination and seeds viability of two primary colonizers of Mediterranean salt pans. Journal of Arid Environments 53: 145-154.

- Sairam, R. K., K. Veerabhadra Rao, and G. C. Srivastava. 2002. Differential response of wheat genotypes to long term salinity stress in relation to oxidative stress, antioxidant activity and osmolyte concentration. Plant Science 163: 1037-1046. 
- Shahbaz,M. M. Ashraf. 2013. Improving salinity tolerance in cereals. Journal Critical Reviews in Plant Sciences. 32: 237-249.

- Shannon M.C. 1997. Adaptation of plants to salinity. Advances in Agronomy 60: 75-120.

- Shrivastava, P., Kumar, R. 2015. Soil salinity: A serious environmental issue and plant growth promoting bacteria as one of the tools for its alleviation. Saudi J. Biol. Sci. 22: 123-131.

- Tsegay, B. A., and B. Gebreslassie. 2014. The effect of salinity $(\mathrm{NaCl})$ on germination and early seedling growth of Lathyrus sativus and Pisum sativum var. abyssinicum. African Journal of Plant Science 5: 225-231.

- Tuteja, N. 2007. Mechanism of high salinity tolerance in plants. In: Methods in Enzymology. pp. 419-438. Hassinger, D., and Sies, H., Eds., Elsevier Inc., Amsterdam, The Netherlands.

- Ungar, I. A. 1996, Effects of salinity on seed germination, growth, and ion accumulation of Atriplex patula (Chenopodiaceae) Amer.J.Bot.83:62-67.

- Wang, Y. R., Kang, S. Z., Li, F. S., Zhang, L., and Zhanf, J. H. 2007. Saline water irrigation through a crop-water-salinity production function and a soil water- salinity dynamic model. Pedosphere. 17: 303-317.

- Zeng, L. and M.C. Shannon. 2000. Salinity effects on seedling growth and yield components of rice. Crop Sci. 40:996-1003.

- Zhang, H. X., J. N. Hodson, J. P. Williams, and E. Blumwald. 2001. Engineering salt-tolerant Brassica plants: characterization of yield and seed oil quality in transgenic plants with increased vacuolar sodium accumulation. Proceedings of the National Academy of Sciences 98: 12832-12836.

- Zhang, J., W. Jia, J. Yang and A.M. Ismail. 2006. Role of ABA integrating plant responses to drought and salt stresses. Field Crop Research. 97: 111-119. 